\title{
Article
}

\section{Microorganisms of the East African Great Lakes and their response to environmental changes}

\author{
Jean-Pierre Descy ${ }^{1} \&$ Hugo Sarmento ${ }^{2}$ \\ ${ }^{1}$ Laboratory of Freshwater Ecology, Research Unit in Organismal Biology, Dept. Biology, University of Namur, Belgium. \\ Email: jpdescy@funp.ac.be \\ ${ }^{2}$ Institut de Ciències del Mar - CMIMA, CSIC, Departament de Biologia Marina i Oceanografia, Barcelona, Catalunya, Spain. \\ Email: hugo.sarmento@gmail.com
}

Received 20 September 2007; accepted 7 January 2008; published 3 March 2008

\section{Abstract}

We have reviewed the phytoplankton composition and succession in the East African Great Lakes, their response to environmental changes, and the communities of microorganisms of the microbial food web. Recent studies in some great lakes, as well as progress in understanding phytoplankton succession and response to environmental factors, enable us to update knowledge of the phytoplankton ecology of these lakes. In particular, we present information indicating that phytoplankton composition in lakes Tanganyika and Kivu may reflect recent changes as a result of global warming or species introduction. We also stress the importance of microbes (at the base of the food web) in these systems and suggest that the microbial food web, which has been mostly overlooked until recently, may play a very large role in determining productivity and nutrient cycling in these large lakes.

Keywords: Phytoplankton; tropical lakes; microbial food web; community changes; Tanganyika; Malawi; Kivu; Victoria; Edward; Albert.

\section{Introduction}

In a context of increased evidence of human-induced climate change and its negative impacts on the world's ecosystems, the productivity of the East African Great Lakes (Fig. 1) has attracted much attention from limnologists, fisheries experts, geochemists and paleolimnologists. Despite the fact that the impact of climate on these ecosystems is still a matter of debate (Sarvala et al., 2006; Verburg et al., 2006), evidence has been accumulating that environmental changes have adversely affected these lakes in recent decades, even though the stories may differ among lakes. Lake Tanganyika and Lake Malawi are threatened by many anthropogenic influences: global warming (Verburg et al., 2003; Verschuren, 2003), fisheries overexploitation (Sarvala et al., 2006), watershed erosion and wastewater discharge (Oguto-Ohwayo \& Hecky, 1991; Lehman, 1996), affecting both the littoral and pelagic ecosystems. In Lake Victoria and Lake Kivu, in addition to these pressures, ecosystem changes have been driven by alien species introduction, with spectacular consequences on ecosystem function, geochemistry, biodiversity, fisheries and socio-economics (Oguto-Ohwayo \& Hecky, 1991; Odada et al., 2003). Recent reports have attempted 


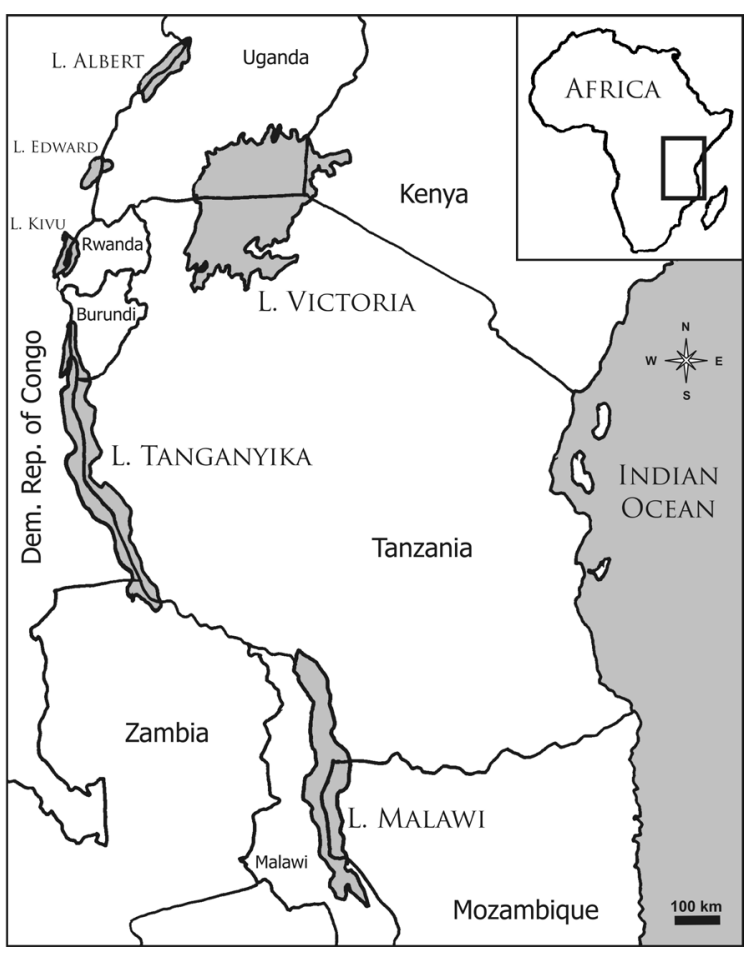

Fig. 1. Map of the East African Rift region, indicating the large lakes and surrounding countries.

to evaluate the present situation in each lake and have stressed the measures to be taken for preserving and restoring these lakes (Odada et al., 2004).

Even though each of these large lakes has unique characteristics, they share some common features:

- They are among the largest and/or deepest lakes in the world; some of them are very old, and their sediments are invaluable archives for paleolimnology and offer opportunities for reconstruction of past climates;

- They are located in the tropics, and they enjoy 'endless summer' (Kilham \& Kilham, 1990); consequently the deepest lakes remain stratified all year round, although there is substantial variation in mixedlayer depth depending on seasonal factors (surface temperature, winds);

- They support a large biodiversity (particularly well known for fishes and some other animal groups);

- The fishery is still an important food resource for local populations: for instance, Lake Tanganyika has a highly productive fishery (Hecky et al., 1981; Coulter, 1991), based on a few, mostly pelagic, species;

- Due to their large size, ecosystem function is dominated by pelagic processes; hence bacteria, phytoplankton and protozoans are a key component of the aquatic community, responding to various factors driven by physical forcing, and whose production and structure determine consumer production and fisheries yield.

The overwhelming importance of phytoplankton in ecosystem processes in large lakes has been emphasised by many authors (e.g. Reynolds et al., 2000), yet the phytoplankton of tropical lakes has received comparatively little attention. In these lakes, the focus of most studies has been on fisheries and animal biodiversity (e.g. Lévêque, 1995), on geochemistry (Craig et al., 1974; Edmond et al., 1993) and on paleolimnology (Haberyan \& Hecky, 1987; Johnson, 1996; Cohen et al., 2005). This is why a review, starting from some key papers on phytoplankton ecology in tropical lakes and incorporating recent data, may be of special interest.

In this paper, we review phytoplankton composition and succession in the East African Great Lakes, their response to environmental changes, and the communities of microorganisms and the microbial food web. The last aspect is fairly new and refers to very recent studies, as studies on microbes in these large lakes were scarce until the 1990s. In particular, we believe that possible changes in food web structure need to be addressed, as they may have large consequences on lake productivity.

\section{Phytoplankton diversity and succession in the East African Great Lakes}

Margalef's differentiation between biodiversity, as the total genetic information present in the ecosystem, and diversity, as the set of core species, responsible for carbon and energy flow in the ecosystem at a particular time (Margalef, 1994, 1997; see also Pedrós-Alió, 2006), fits perfectly well with the history of phytoplankton research in the East African Rift region. The first scientific expeditions basically consisted of taxonomical studies and led to the description of many 
species, some of them new to science (in Lake Tanganyika: e.g. West, 1907; Van Meel, 1954; in Lake Kivu: Hustedt, 1949; Frémy et al., 1949; in Lake Malawi: e.g. Schmidle, 1898, 1902; Iles, 1960; in Lake Victoria: e.g. West, 1907; Woloszynska, 1914; Bachman, 1933; Fish, 1952; Evans, 1962a, b). A complete reference list and a floristic inventory of the pelagic and benthic algae of the East African Great Lakes can be found in Cocquyt et al. (1993) and Cocquyt \& Vyverman (1994). In a second stage, a number of studies were published addressing the dynamics of the dominant phytoplankton species, to increase understanding of the ecology of these pelagic algal communities. In this review we will attempt to update the review by Talling (1986) and the comparative study by Hecky \& Kling (1987), with an analysis at the diversity level (sensu Margalef) focusing on the functional aspects of the dominant assemblages of phytoplankton in the East African Great Lakes.

Contrary to the common assumption that in tropical regions the 'endless summer' dictates very constant conditions with only subtle contrasts between seasons, it has been demonstrated that the algal succession in the East African Great Lakes is largely influenced by meteorological conditions and by the physical constraints that differ during a year cycle (e.g. Lemoalle et al., 1981; Talling, 1986; Hecky \& Kling, 1987; Sarmento et al., 2006). The East African region is characterised by a dry season with south-eastern dominant winds (from June to September), and a calmer and warmer rainy season (October to May). Near the equator (Lakes Kivu and Victoria) a short dry season might be defined around January, when the winds can be stronger than in typical rainy season conditions (Talling, 1966; Sarmento et al., 2006), which will obviously influence the seasonal variations of phytoplankton abundance and composition.

Hecky \& Kling (1981) published a seasonal cycle of the phytoplankton (and protozooplankton) species composition, biomass and chlorophyll $a$ in Lake Tanganyika. A chlorophyte (Chroococcales) assemblage was described as characteristic of the wet season (October to April), with high light and poor nutrient availability in the shallow epilimnion. In the dry season (May to September), when deep mixing occurred, diatom (mostly Nitzschia spp.) dominance was explained by the lower light levels and higher nutrient availability. Surface blooms of filamentous Cyanobacteria (Anabaena spp.) developed at the end of the dry season, when the water column restratified. The Tanganyika phytoplankton record was completed by cruise samples that allowed spatial variation to be determined (Hecky \& Fee, 1981; Hecky \& Kling, 1987). At least three other papers were published on the seasonal dynamics of phytoplankton in the following years, but oriented to a specific algal group (diatoms) or restricted to littoral areas (Cocquyt et al., 1991; Cocquyt, 1999, 2000). More recently, both algal pigment (Descy et al., 2005) and microscopy (Cocquyt \& Vyverman, 2005) surveys have provided current data on algal biomass, composition and dynamics in the pelagic waters of Lake Tanganyika, and have underlined the Cyanobacteria-chlorophyte dominance during the primary portion of the annual cycle, showing a particular prominence of the picocyanobacteria Synechococcus spp. (Vuorio et al., 2003; Descy et al., 2005; Sarmento et al., 2008). There is, however, significant spatial variation in Lake Tanganyika. The dry season diatom peak (comprising the colonial Nitzschia cf. asterionelloides O. Müll.), coinciding with the chlorophyll $a$ maximum in the water column (Cocquyt \& Vyverman, 2005), is clearly visible in the northern part of the lake. In contrast, in the southern basin, where the temperature density gradient is usually weaker, diatom development does not follow a clear seasonal pattern, and picocyanobacteria tend to dominate at all times (Descy et al., 2005). Another Nitzschia species, identified as N. fonticola Grun., is more characteristic of the stratified conditions of the rainy season (Cocquyt \& Vyverman, 2005), particularly in the southern part of the lake. These same recent investigations (Descy et al., 2005), indicate that green algae are far more abundant and diverse in the region of Kigoma (northern basin) than offMpulungu (southern basin). Lobocystis planctonica Tiffany et Ahlstrom was often found to be the dominant green alga; also worth mentioning are the endosymbionts in ciliates, previously referred to as 'zoochlorellae' by Hecky \& Kling (1981), and identified as Siderocelis irregularis Hindák, by Stoyneva et al. (2008). Several floristic differences in the green algal assemblages of these two lake areas have also been shown 
(Stoyneva et al., 2007a), with taxonomic updates and new species descriptions (Stoyneva et al., 2005, 2006, 2007b).

Farther from the equator, Lake Malawi has a weaker thermal gradient and the dry season mixing has a greater extent than in other East African Great Lakes: Patterson \& Kachinjika (1995) reported a mixed layer reaching $230 \mathrm{~m}$ in the central part of the lake (Nkhotakota) in August/ September 1992/1993. In an analogous region of Lake Tanganyika (Kigoma), Descy et al. (2006) never observed a mixed layer deeper than $80 \mathrm{~m}$ during a three-year survey (2002-2004). The rainy season algal assemblages in Lake Malawi are fairly comparable to those described for Lake Tanganyika, with chlorophytes (Chlorococcales such as Coenococcus spp. or Lobocystis spp.) and some Cyanobacteria (such as Planktolyngbya spp.), but diatom prominence during the dry season seems more marked (Hecky \& Kling, 1987; Haberyan \& Mhone, 1991; Bootsma, 1993; Patterson \& Kachinjika, 1995). Within the dry season, a diatomdominated community comprising various Nitzschia taxa usually develops first, followed by centric diatoms, such as Stephanodiscus spp. and Cyclostephanos spp., that codominate the algal community along with the chlorophyte Mougeotia spp. The diatom assemblage shift may well indicate a change in resource ratios driven by the deeper mixing and nutrient uptake by phytoplankton: the diatom succession is consistent with a decrease in the Si:P ratio, in agreement with the hypothesis of Kilham et al. (1986), who classified planktonic diatoms according to their probable

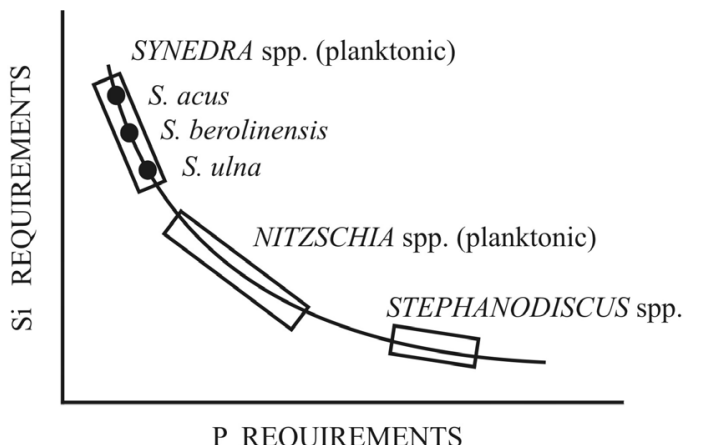

Fig. 2. Hypothetical growth relationship for planktonic diatoms from Africa as a function of phosphorus and silica requirements. Synedra refers to Fragilaria, according to current taxonomy. (Redrawn from Kilham et al., 1986).
$\mathrm{Si}$ and $\mathrm{P}$ requirements (Fig. 2). It is interesting to note here that, according to published records, Stephanodiscus, Cyclostephanos and Aulacoseira are not found in the Lake Tanganyika phytoplankton off Kigoma (Cocquyt \& Vyverman, 2005); this would be consistent with differences in patterns of vertical mixing between both lakes.

For Lake Kivu, a smaller rift lake located north of Lake Tanganyika, Hecky \& Kling (1987) reported a Cyanobacteria-chlorophyte dominated phytoplankton at that time similar to that in the larger Rift lakes. This description of Lake Kivu phytoplankton was, however, based on few samples collected in the 1970s. Kilham et al. (1986) reported a dominance (within the diatom population) of needle-like Fragilaria and Nitzschia in the largest northern basin and in Kabuno Bay, in agreement with the high dissolved Si:P ratio reported for these lake parts, while Stephanodiscus was more abundant in the southern, holomictic, Bukavu Bay, where dissolved Si:P was much lower. A more complete study, based on microscopy and marker pigments, by Sarmento et al. (2006, 2007) showed that, more recently (2002-2005), the phytoplankton in Lake Kivu was dominated by diatoms (Urosolenia spp., Nitzschia bacata Hust. and Fragilaria danica Lange-Bert.), particularly during the dry season episodes of deep mixing. During the rainy season, the stratified water column favoured dominance of filamentous Cyanobacteria (namely Planktolyngbya limnetica Lemm.) and of picocyanobacteria (Synechococcus spp.; Sarmento et al., 2008). Green algae were found to be always a minor plankton component at several sample locations on Lake Kivu, well below diatoms, Cyanobacteria, cryptophytes and chrysophytes. This peculiar phytoplankton assemblage points to substantial differences in water column structure and transparency between Lake Kivu and its larger neighbours, despite a similar range of primary production and nutrient concentrations (Sarmento, 2006; Sarmento et al., 2006).

The situation in Lake Victoria, which can be described from historical data prior to the eutrophication of this lake, is substantially different from that of the other East African lakes. Talling's detailed records from the 1950s (Talling, $1957,1966,1987)$ enable observations of the eutrophication 
process which started in the early 1960s following the introduction of the Nile perch (Lates niloticus Lin.) and the Nile tilapia (Oreochromis niloticus Sci.) into this lake, and the increasing human population along its shores (Hecky, 1993; Mugidde, 1993; Hecky et al., 1994; Gophen et al., 1995; Kling et al., 2001; Verschuren et al., 2002; Silsbe et al., 2006). The abundant literature on recent changes emphasises an increasing persistency of a reduced number of Cyanobacteria taxa (namely Cylindrospermopsis and Anabaena) along with a decrease of species number in diatoms.

The amount of data found in the literature concerning phytoplankton in Lakes Edward and Albert is, comparatively, very restricted. In the same study cited above for other East African lakes, Hecky \& Kling (1987) reported some results from a sampling campaign in March 1972. At that time, Lake Edward had a relatively high biomass, dominated by Cyanobacteria (Microcystis spp., Chroococcus spp. and Merismopedia) and chlorophytes (Planktonema lauterborni Skuja, Tetraedron spp., Oocystis spp., Scenedesmus spp. and Lagerheimia subsalsa Lemm.). Algal biovolume in Lake Albert was low, in the same order of magnitude as Lakes Malawi and Tanganyika, and the dominant taxa were Stephanodiscus (now Cyclostephanos) spp. (largely dominant), Ochromonas, Chromulina and Bisocoeca, along with a few chlorophytes such as Ankyra paradoxoides Cirile and Schroederia setigera (Schröder) Lem. One, almost complete, year-cycle on phytoplankton biomass and composition in Lake Albert was published by Evans (1997), but the samples were taken in 19611962. At that time the phytoplankton was dominated by diatoms and Cyanobacteria. Evans confirmed the Stephanodiscus spp. dominance, but also highlighted the considerable abundance of Nitzschia spp. and Anabaena flos-aquae (Bréb.) Bornet et Flah. in other periods of the year.

\section{Phytoplankton structure as an indicator of ecological changes}

Changes in Lake Victoria brought about by food web alterations and increasing human pressure on its watershed have been well documented, due to the existence of detailed past and present phytoplankton data (Talling, 1966; Hecky,
1993) and the availability of diatom records in the sediment (Haberyan \& Hecky, 1987). The recent phytoplankton studies in Lake Tanganyika and Lake Kivu provide other examples of how phytoplankton assemblages may reflect geochemical and ecological changes which have been related to environmental changes.

Verburg et al. (2003) presented a strong case for a significant global warming impact and reduction of primary production in Lake Tanganyika, based on rise of temperature in the surface waters, increase in transparency associated with a decrease in phytoplankton biovolume, and change in $\mathrm{Si}$ concentration in the euphotic layer. Although some arguments can be challenged (see Descy et al., 2005 and Sarvala et al., 2006), evidence from the observed increase in Si concentration relates well to a reduction in diatom abundance and a change in diatom composition in the phytoplankton. Silica measurements over several decades indicate that $\mathrm{Si}$ in the upper $50 \mathrm{~m}$ has tripled, while no change has occurred below $100 \mathrm{~m}$. According to Verburg et al. (2003), 'The increase in silica in the mixed layer is a result of decreased diatom production, driven by a lower availability of nutrients such as phosphorus. Nutrient limitation lowers diatom sedimentation rates, and silica accumulates in the mixed layer'. Alleman et al. (2005) confirmed the increasing Si trend, with current concentrations of surface dissolved Si of $32 \pm 8 \mu \mathrm{mol} \mathrm{L}^{-1}$ compared to the 1938-1975 period $\left(9.5 \pm 4.6 \mu \mathrm{mol} \mathrm{L}^{-1}\right)$, and estimated an increase rate of about $70 \mathrm{mmol} \mathrm{m}^{-2} \mathrm{yr}^{-1}$ over the last 28 years (1975-2003), with no corresponding change in Si loading from the tributaries of the lake. In the same period of time, a change in composition occurred in the lake diatom assemblage. Hecky \& Kling (1987) clearly mentioned peaks of Stephanodiscus (now Cyclostephanos) spp. occurring in the dry season, followed by a peak of Nitzschia spp. These data from the 1970s are confirmed by the abundance of Cyclostephanos., as well as of Nitzschia spp. (gr. lanceolatae) and even of Aulacoseira granulata (Ehrenberg) Simonsen in the sediment (Haberyan \& Hecky, 1987). In contrast, recent studies showed dominance of the dry season peaks by Nitzschia asterionelloides O.Müll. (Cocquyt \& Vyverman, 2005), and the absence of other planktonic diatom taxa. This compositional change fits very well 
with the observed increase of Si:P ratio in the surface water of Lake Tanganyika, as a result of the warming trend, which strengthened stratification and reduced P supply to the euphotic layer, reducing primary production and affecting particularly the dry season diatom development. Indeed, we may infer from $N$. asterionelloides morphology that it is a better competitor for $\mathrm{P}$, due to its narrow and elongated shape, and that it should therefore be located in the medium part of the Si:P gradient and better adapted to the changed conditions in Lake Tanganyika, while Cyclostephanos was virtually excluded as a result of its higher P requirements. Also, Nitzschia asterionelloides is a colonial form, with settling properties which allow it to concentrate in the lower part of the euphotic zone under stratified conditions (Descy et al., 2005); accordingly, these diatoms have a remarkably low concentration of the photoprotective xanthophyll diadinoxanthin (Descy et al., 2005). This taxon, therefore, appears to be better adapted to the strengthened stratification of Lake Tanganyika (shallower mixed layer during a longer stratification period) that occurs as a result of surface warming and to the decreased strength of the prevailing trade winds. Possibly, higher specific settling velocities might have contributed to the exclusion of the Stephanodiscus taxa.

Recent and important geochemical changes relating to biological processes may also have occurred in Lake Kivu, with a possible response at the phytoplankton level. Surprisingly at first glance, the chemical changes in Lake Kivu appear to be opposite to those in Lake Tanganyika: surface Si concentrations have decreased since the 1970s (100 $\mu \mathrm{mol} \mathrm{L}{ }^{-1}$ now vs. $290 \mu \mathrm{mol} \mathrm{L}^{-1}$; Sarmento et al., 2006) whereas Si and P concentrations below the chemocline have increased (25-30\% for $\mathrm{Si}$ and by a factor of 3 for P; Schmid et al., 2005). During the same period of time, substantial changes in gas concentrations have occurred in the deep waters of the lake. Compared to previous measurements in the 1970s (Tietze et al., 1980), the measured $\mathrm{CH}_{4}$ concentrations in the deep waters have increased by $15-20 \%$ and $\mathrm{CO}_{2}$ concentrations by about $10 \%$ (Schmid et al., 2005). Given that this gas increase has required an increased input of organic carbon to the monimolimnion, it would be tempting to hypothesise that the lake underwent anthropogenic eutrophication and that a part of the increased planktonic production was exported to the sediment, where most of the methane formation occurs. Indeed, human population density has increased around Lake Kivu in recent decades, which as a result increased nutrient input from the watershed. However, measurements of primary production using ${ }^{14} \mathrm{C}$ incubations have not shown a substantial change in the range of values compared to those measured in the 1970s (Sarmento, 2006). An alternative explanation may be that a larger part of the primary production, consisting of diatoms, has been exported from the surface to the deep waters; this would be consistent with $\mathrm{Si}, \mathrm{P}$ and $\mathrm{CH}_{4}$ increases in these layers, while primary production did not change substantially. The hypothesis of an increased $\mathrm{C}$ vertical flux is supported by a few facts. First, Lake Kivu chlorophyll $a$ concentration is two to three times higher than that in the northern part of Lake Tanganyika, with similar climate and nutrient conditions, and with a similar range of depth-integrated primary production. Second, a key feature of Lake Kivu is its food web, without control of the planktivores by predation: the top consumer in Lake Kivu is the zooplanktivorous clupeid Limnothrissa miodon Boulanger (the Tanganyika sardine), an endemic from Lake Tanganyika introduced in the 1950s to develop a pelagic fishery. This introduction, which has been successful as far as the fishery is concerned, has had dramatic effects on the zooplankton, resulting in the disappearance of the largest and most efficient grazer (Dumont, 1986; Isumbisho et al., 2006) and probably a substantial reduction of copepod abundance. The lower grazing pressure which has resulted from reduction in zooplankton structure and abundance may explain why the present phytoplankton biomass is higher in Lake Kivu than in Lakes Tanganyika and Malawi, having a similar level of primary production.

Although few data are available from past studies, the phytoplankton community structure in Lake Kivu may also have changed. Hecky \& Kling (1987), while also noticing greater phytoplankton abundance in Lake Kivu than in Malawi and Tanganyika, mentioned dominance by Cyanobacteria and chlorophytes, more significant dinoflagellate development than in other lakes, and 
diatoms only in an isolated bay. Today, diatoms are the most abundant phytoplankton group in Lake Kivu, and cryptophytes are well developed, whereas chlorophytes are much less represented (Sarmento et al., 2006). These changes are consistent with lower light availability as a result of decreased water transparency, due to increased chlorophyll $a$. Furthermore, the diatom assemblage of Lake Kivu comprises large slower growing, inedible, pennate diatoms (chiefly Fragilaria danica and Nitzschia bacata), which may have contributed, by their sedimentation, to the increase in export flux of $\mathrm{C}, \mathrm{Si}$ and $\mathrm{P}$ from the surface to the deep layers, and thus to the geochemical changes mentioned above. In summary, the introduction of the Tanganyika sardine, through a trophic cascade effect which ultimately favoured diatom production, may have had the unexpected consequence of enhancing methane formation in the monimolimnion, with a possible hazardous outcome for the local populations (Bellanger, 2007).

\section{Do changes in phytoplankton composition affect zooplankton abundance and fish yields?}

There has been rising concern about the changes in fisheries in the African Great Lakes, starting with the dramatic changes that occurred in Lake Victoria as a result of eutrophication, invasive species (the water hyacinth in particular), and the Nile perch and Nile tilapia introductions with the associated species loss (OgutoOhwayo \& Hecky, 1991). Climate change may also have contributed to greater stratification, which promoted changes in the phytoplankton, with loss of diatoms and success of Cyanobacteria, deoxygenation of the hypolimnion and loss of habitat (Lehman, 1996). Dumont (1986) speculated that the developing fishery in Lake Kivu was doomed by the adverse effect of the introduced sardine on zooplankton, its main resource. More recently, evidence has accumulated that other Rift lakes are threatened, most notably Lake Tanganyika, with reports of declining primary production related to global warming (O'Reilly et al., 2003; Verburg et al., 2003) and overexploitation (Sarvala et al., 2006). Other problems have been identified in several studies, summarised in general reviews such as those by Odada et al. $(2003,2004)$. Fisheries are of course of primary importance for the local populations, with annual catches of 30000 metric tonnes for Lake Malawi, and up to 100000 metric tonnes for Lake Tanganyika (Bootsma \& Hecky, 2003).

As classic models based on statistical relationships between primary production and fish yield have shown (Melack, 1976), one may expect that reduced phytoplankton production in pelagic systems will result in decreased fish production. This has been observed in Lake Tanganyika, for which Plisnier (2004) has shown correlations between ENSO (El Niño-Southern Oscillation) indices and the catches (CPUE, catch per unit effort) of the main species exploited by the fishery. Although an impact of the fishing effort is still probable, as a decline in the industrial fishery was more than compensated by a rise in artisanal catches (Sarvala et al., 2006), the evidence for a climatedriven productivity change, affecting primary production with an expected impact on pelagic fish production, is fairly strong (Verburg et al., 2006; Stenuite et al., 2007).

In this debate, the efficiency of carbon transfer through the food web has not been explicitly considered, despite the fact that there are signs of substantial changes in the structure of planktonic assemblages in Lake Tanganyika which have not been documented yet for other Great African lakes.

Recent studies (Pirlot et al., 2005) have shown that a substantial fraction of producer biomass in Lake Tanganyika is represented by picoplankton (Fig. 3), comprising heterotrophic bacteria and picocyanobacteria, later identified as Synechococcus (Stéphane Stenuite, personal communication). In the southern part of the lake, the proportion of picoplankton biomass may reach $80 \%$ of the total phytoplankton biomass. In a broad comparison of aquatic systems, Sarmento et al. (2008) have shown that picocyanobacteria abundance and biomass in Lake Tanganyika is among the largest known worldwide. Moreover, bacterial production in Lake Tanganyika approaches the range of particulate primary production (Pirlot, 2006), and a major fraction of this production is grazed by heterotrophic nanoflagellates and ciliates (Pirlot 
a)

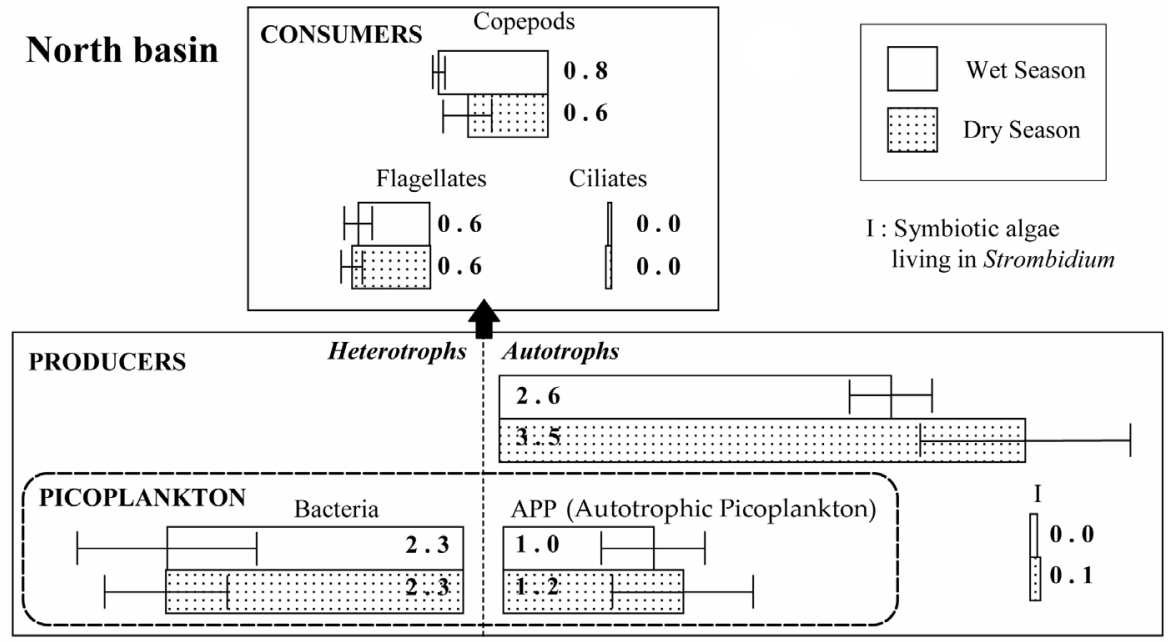

b)

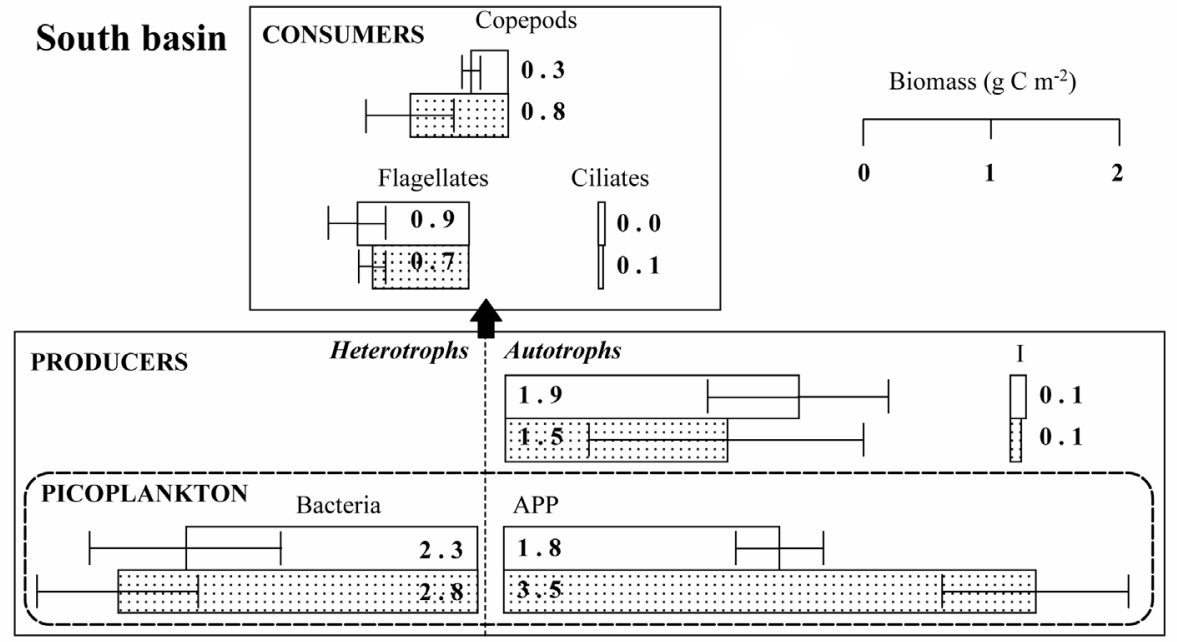

Fig. 3. Biomass of different plankton compartments in Lake Tanganyika, integrated in the $0 \mathrm{~m}-100 \mathrm{~m}$ water column. (a) Northern basin off Kigoma; (b) Southern basin off Mpulungu (data from 2002-2005; redrawn with permission from Pirlot et al., 2005).

et al., 2007). Results from grazing experiments (Stenuite et al., personal communication) have demonstrated that heterotrophic nanoflagellates and ciliates actively graze upon all picoplankton, with a preference by the former, which are the main grazers, for picocyanobacteria. These data clearly reinforce the concept that consumer production in Lake Tanganyika is supported in a substantial way by heterotrophic production, which takes place in the whole oxic layer (down to $100 \mathrm{~m}$ depth), while primary production is confined to the euphotic layer (Hecky et al., 1981). In other words, the microbial food web seems to be well developed in the lake, and plays a key role in organic matter transfer from the primary producers to the metazoans, as well as in nutrient regeneration. In this respect, the Lake Tanganyika pelagic zone appears very close to oligotrophic marine systems in ecological functioning.

But what is the overall trophic efficiency of a system dominated by a microbial food web? Theoretically, one may expect that trophic efficiency would be lower in a system dominated by the microbial loop, where additional steps and high respiration rates contribute to large 
organic carbon losses, even if heterotrophic protists are grazed upon by metazooplankton. This hypothesis has been tested experimentally by Berglund et al. (2007) who obtained a $2 \%$ trophic efficiency in a bacteria-based system, compared with $22 \%$ in a phytoplankton-based system, where most phytoplankton production passed directly to the metazoan grazers. One may question to what extent the present Lake Tanganyika, with its longer stratification periods as a result of global warming, its diminished primary production and a high bacterial production, is not analogous to the bacteria-based system. Furthermore, as mentioned above, the phytoplankton community changes may have affected consumer production in Lake Tanganyika. Diatom production, which takes place mostly during deep mixing events, has decreased (Verburg et al., 2003), and species favoured by deep mixing and increased $\mathrm{P}$ availability have virtually disappeared. It is likely that both autotrophic and heterotrophic picoplankton have increased as a result of increased stratification and temperature, and lower nutrient availability (Agawin et al., 2000; Cotner \& Biddanda, 2002). Among phytoplankters, Synechococcus has adaptations suited to the high-light environment of a shallower epilimnion, with its high cell content of photoprotective pigment (Falkowski \& Raven, 1997), which fits well with its dominance in the upper mixed layer in Lake Tanganyika in rainy season conditions.

The picture of the present Lake Tanganyika food web which arises from these recent studies, possibly as a result of global warming, is substantially different from what was described from data of the 1970s: - In the stratified conditions of the rainy season, possibly enhanced in ENSO years, with warmer temperatures and lower wind velocities (Plisnier, 2000), picocyanobacteria dominate, along with green algae (mostly colonial), and with short-lived events of surface Anabaena blooms; high light exposure in the shallow mixed layer promotes extracellular DOC (dissolved organic carbon) release by phytoplankton cells which, together with mortality of different phytoplankton components, provides heterotrophic bacteria with labile DOM (dissolved organic matter) and helps increase bacterial production. In such conditions, the system is picoplankton-dominated and most of the production goes to the microbial food web, lowering trophic efficiency but enhancing nutrient cycling in the euphotic zone; when Anabaena blooms occur, the collapse by mortality of these Cyanobacteria would probably fuel the microbial loop rather than providing food directly to the metazooplankton.

- In dry-season conditions, deep mixing and improved nutrient availability favour diatom development, as was described by Hecky \& Kling (1987); the fast, positive, response of metazooplankton to these diatoms (Kurki, 1999) indicates direct trophic transfer of high-quality food. Internal nutrient loading from the hypolimnion dominates in most of the lake, and upwellings at the southern tip of the lake add substantial amounts of nutrients to the euphotic layer, allowing 'new production' to take place. Most of the lake consumer production, including fish, depends on these wind-driven dry season events and hence is also dependent on climate variability.

A similar impact of climate variability has been described to explain reduced productivity in the ocean from lower trophic efficiency in ENSO years (Karl et al., 2002), and oligotrophication in some European mountain lakes (e.g. Anneville et al., 2005).

\section{Perspectives}

The recent studies in some of the East African Great Lakes, mainly on the smaller size compartments of the food web (see above), may have introduced new concepts to tropical limnology. New challenges must be overcome to understand the functioning of these systems and their response to the environmental changes expected, or already taking place, in this century. The study of microbes requires advanced technology, and the application of technologies like flow cytometry, epifluorescence microscopy or molecular techniques in remote African regions is certainly one of these challenges. At present, the simple problem of sample preservation is still an inevitable obstacle for producing good science in most parts of Africa. 
A significant amount of work remains to be done in some lakes (for example, Malawi, Victoria, Edward and Albert), in order to obtain such basic information as auto- and heterotrophic picoplankton biomass, diversity, and its importance in the pelagic food webs. Heterotrophic and mixotrophic protists, already identified decades ago as key components of the food web, are virtually unknown in some of the largest lakes, whereas there are indications that they are an important link between producers and consumers, and may be an important component in nutrient recycling.

Research in the past decades has focused on the largest of the Rift lakes (Victoria, Tanganyika and Malawi), which have offered the most fascinating opportunities for science, both because of their outstanding characteristics and also because of the numerous problems they have faced. Attention has been drawn to the need for their conservation. In contrast, the smaller of the Rift lakes have been almost totally ignored, with the exception of Lake Kivu, for which recent results are available. Complete and updated limnological and plankton studies are still missing for some of the lakes (Edward and Albert), which are no less important for the local population.

On the other hand, there are practically no molecular studies on microbes in this part of the world, with the notable exception of Lake Tanganyika (de Wever et al., 2005) and of ongoing studies, still unpublished, on photosynthetic and heterotrophic picoplankton. A major research topic for such ancient lakes would be to examine the microbial food web with molecular methods, despite the fact that we may expect less diversity in microorganisms than in the larger vertebrates or invertebrates, and may look for possible endemism or simply detect forms of life which have gone undetected by other methods.

Another obstacle to improving scientific knowledge and, above all, resources management, is that all these lakes are shared by more than one country (Fig. 1). The organisation of a sampling cruise crossing different countries can easily turn into an enormous task. More alarming is the fact that tropical lakes theoretically show a higher degree of adverse response to eutrophication or organic loading than would occur in temperate lakes (Lewis, 2000). In the case of the East
African Great Lakes, with integrated management actions requiring international agreements, the potential problems arising from increasing populations along the lakes shores, species introductions, environmental degradation and global warming therefore take on another dimension.

Finally, when compared to the proportion of surface fresh water in the world, the attention given by the scientific community to this part of the world is rather low, as can be easily seen by a web-based literature search, using simple key words (Fig. 4). Why is this, at a time in which global resources and sustainable development are major concerns for the large international organisations,

a) Wetlands, Lakes and Rivers $\left(\mathrm{km}^{3}\right)$

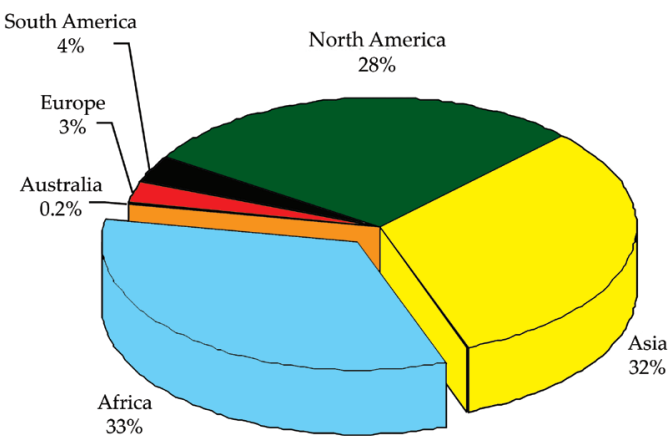

b)

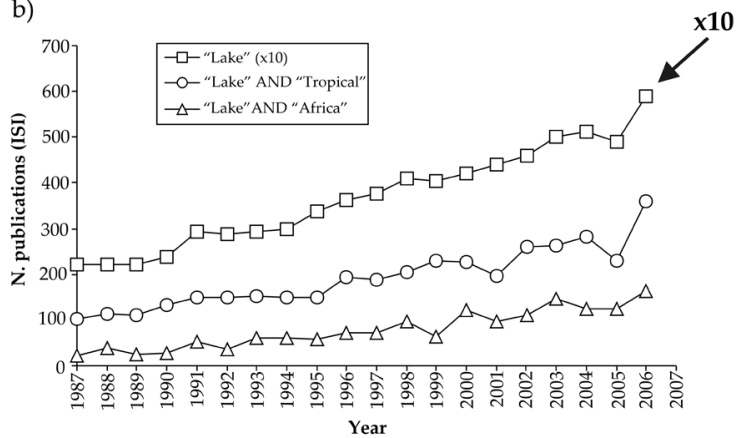

Fig. 4. (a) Distribution of surface fresh water (wetlands, lakes and rivers) among the world continents and subcontinents, highlighting the high proportion found in the African continent. (Source: United Nations Environment Program, http://wwww.unep. org/dewalassessments/ecosystems/water/vitalwater/02.htm). (b) Number of publications recorded in ISI Web of Knowledge containing the keywords 'Lake' (squares), 'Lake' AND 'Tropical' (circles), 'Lake' AND 'Africa' (triangles). (Note that the number of publications for the keyword 'Lake' was divided by 10 to keep on the same scale). 
and for the large proportion of the world population living in developing countries? One of the reasons may be that, among the community of local scientists and technicians, few have received adequate training, not to mention the unattractive salaries and the lack of financial and technical means for undertaking research and sustaining the effort. Fortunately, a generation of African students is emerging which has benefited from the support of well-funded projects and who have become involved in studies of the aquatic ecosystems in their own countries. However, more initiatives of scientific and technical cooperation are still needed, and thanks to them, and to rising awareness of the environmental problems threatening fresh waters, the local scientific communities in Africa will develop the capacity for science-based management of their remarkable natural resources.

\section{Acknowledgements}

Numerous studies cited in this paper were supported by different Belgian institutions: for Lake Tanganyika, by the Belgian Science Policy Office (projects CLIMLAKE and CLIMFISH), FNRS (Fonds de la Recherche Scientifique), and the Belgian Technical Cooperation (BTC); for Lake Kivu, the University of Namur and CUD (Commission Universitaire pour le Développement) which financed the ECOSYKI project, provided the main support. Several students from the Laboratory of Freshwater Ecology benefited from fellowships from FRIA ('Fonds pour la formation à la Recherche dans l'Industrie et dans l'Agriculture'), FNRS, BTC, IFS (International Foundation for Science), SIL (International Society of Limnology), 'King Léopold III Fund for Nature Exploration and Conservation' and 'Foundation to Promote Scientific Research in Africa'. We are also indebted to the Department of Fisheries (DOF) of Mpulungu, Zambia, to the Tanzanian Fisheries Research Institute (TAFIRI), Kigoma, Tanzania and to the Unité d'Enseignement et de Recherche en Hydrobiologie Appliquée (UERHA) of the Institut Supérieur Pédagogique (ISP), Bukavu, D.R. of Congo. Finally, we thank the editor, C.S. Reynolds, who invited us to write this review, and two anonymous reviewers who helped improve the manuscript.

\section{References}

Agawin, N.S.R., Duarte, C.M. \& Agusti, S. (2000). Nutrient and temperature control of the contribution of picoplankton to phytoplankton biomass and production. Limnology $\mathcal{E}$ Oceanography 45, 591-600.

Alleman, L.Y., Cardinal, D., Cocquyt, C., Plisnier, P.D., Descy, J.-P., Kimirei, I., Sinyinza, D. \& Andre, L. (2005). Silicon isotopic fractionation in Lake Tanganyika and its main tributaries. Journal of Great Lakes Research 31, 509-519.

Anneville, O., Gammeter, S. \& Straile, D. (2005). Phosphorus decrease and climate variability: mediators of synchrony in phytoplankton changes among European peri-alpine lakes. Freshwater Biology 50, 1731-1746.

Bachmann, H. (1933). Phytoplankton von Victoria Nyanza, Albert Nyansa und Kogasee. Berichte der Schweizerischen Botanischen Gesellschaft 42, 705-717.

Bellanger, B. (2007). Lac Kivu, l'Eldorado énergétique qui fait peur. Science \& Vie 1082, 104-111.

Berglund, J., Müren, U., Bamstedt, U. \& Andersson, A. (2007). Efficiency of a phytoplankton-based and a bacterial-based food web in a pelagic marine system. Limnology and Oceanography 52, 121-131.

Bootsma, H.A. (1993). Spatio-temporal variation of phytoplankton biomass in Lake Malawi, Central Africa. Verhandlungen der Internationalen Vereinigung für theoretische und angewandte Limnologie 25, 882-886.

Bootsma, H.A. \& Hecky, R.E. (2003). A comparative introduction to the biology and limnology of the African Great Lakes. Journal of Great Lakes Research 29, Suppl. 2, 3-18.

Cocquyt, C. (1999). Seasonal dynamics of diatoms in the littoral zone of Lake Tanganyika, Northern Basin. Algological Studies 92, 73-85.

Cocquyt, C. (2000). Biogeography and species diversity of diatoms in the northern basin of Lake Tanganyika. Advances in Ecological Research 31, 125-150.

Cocquyt, C. \& Vyverman, W. (1994). Composition and diversity of the algal flora in the East African Great Lakes: a comparative survey of lakes Tanganyika, Malawi (Nyasa), and Victoria. 
Archiv für Hydrobiologie Beihefte Ergebnisse der Limnologie 44, 161- 172.

Cocquyt, C. \& Vyverman, W. (2005). Phytoplankton in Lake Tanganyika: a comparison of community composition and biomass off Kigoma with previous studies 27 years ago. Journal of Great Lakes Research 31, 535-546.

Cocquyt, C., Caljon, A. \& Vyverman, W. (1991). Seasonal and spatial aspects of phytoplankton along the north-eastern coast of Lake Tanganyika. Annales de Limnologie 27, 215-225.

Cocquyt, C., Vyverman, W. \& Compére, P. (1993). A check-list of the algal flora of the East African Great Lakes: Lake Malawi, Lake Tanganyika and Lake Victoria. Scripta Botanica Belgica 8, $1-54$.

Cohen, A.S., Palacios-Fest, M.R., McGill, J., Swarzenski, P.W., Verschuren, D., Sinyinza, R., Songori, T., Kakagozo, B., Syampila, M., O'Reilly, C.M. \& Alin, S.R. (2005). Paleolimnological investigations of anthropogenic environmental change in Lake Tanganyika: I. An introduction to the project. Journal of Paleolimnology 34, 1-18.

Cotner, J.B. \& Biddanda, B.A. (2002). Small players, large role: microbial influence on biogeochemical processes in pelagic aquatic ecosystems. Ecosystems 5, 105-121.

Coulter, G.W. (ed). (1991). Lake Tanganyika and its Life. Oxford University Press, London. 354 pp.

Craig, H.D.F., Craig, V., Edmond, J. \& Coulter, G. (1974). Lake Tanganyika Geochemical and Hydrographic Study: 1973 expedition. Publication Scripps Institution of Oceanography Series $75,1-83$.

de Wever, A., Muylaert, K., Van der Gucht, K., Pirlot, S., Cocquyt, C., Descy, J.-P., Plisnier, P.D. \& Vyverman, W. (2005). Bacterial community composition in Lake Tanganyika: vertical and horizontal heterogeneity. Applied and Environmental Microbiology 71, 5029-5037.

Descy, J.-P., André, L., Vyverman, W. \& Deleersnijder, E. (2006). Climate variability as recorded in Lake Tanganyika (Climlake). Belgian Science Policy, Brussels. 119 pp.

Descy, J.-P., Hardy, M.-A., Sténuite, S., Pirlot, S., Leporcq, B., Kimirei, I., Sekadende, B., Mwaitega, S.R. \& Sinyenza, D. (2005). Phytoplankton pigments and community composition in Lake Tanganyika. Freshwater Biology 50, 668-684.

Dumont, H.J. (1986). The Tanganyika sardine in Lake Kivu: another ecodisaster for Africa? Environmental Conservation 13,
143-148.

Edmond, J. M., Stallard, R.F., Craig, H., Craig, V., Weiss, R. F. \& Coulter, G.W. (1993). Nutrient chemistry of the water column of Lake Tanganyika. Limnology and Oceanography 38, 725-738.

Evans, J.H. (1962a). The distribution of phytoplankton in some Central East African waters. Hydrobiologia 19, 299-315.

Evans, J.H. (1962b). Some new records and forms of algae in Central East Africa. Hydrobiologia 20, 59-86.

Evans, J.H. (1997). Spatial and seasonal distribution of phytoplankton in an African Rift Valley lake (L. Albert, Uganda, Zaire). Hydrobiologia 354, 1-16.

Falkowski, P. G., \& Raven, J. A. (1997). Aquatic Photosynthesis. Blackwell Science. 375 pp.

Fish, G.R. (1952). Hydrology and Algology - Annual Report. East African Fisheries Research Organisation, Jinja (Uganda). 49 pp.

Frémy, P., Pascher, A. \& Conrad, W. (1949). Exploration du Parc National Albert - Mission H. Damas 1935-1936. Fascicule 19: Algues et Flagellates. Institut des Parcs Nationaux du Congo Belge, Brussels. 93 pp.

Gophen, M., Ochumba, P.B.O. \& Kaufman, L.S. (1995). Some aspects of perturbation in the structure and biodiversity of the ecosystem of Lake Victoria (East Africa). Aquatic Living Resources 8, 27-41.

Haberyan, K.A. \& Hecky, R.E. (1987). The late Pleistocene and Holocene stratigraphy and paleolimnology of lakes Kivu and Tanganyika. Paleogeography, Paleoclimatology, Paleoecology 61, 169-197.

Haberyan, K.A. \& Mhone, O.K. (1991). Algal communities near Cape Maclear, southern Lake Malawi, Africa. Hydrobiologia 215, 175-188.

Hecky, R.E. (1993). The eutrophication of Lake Victoria. Verhandlungen der Internationalen Vereinigung für theoretische und angewandte Limnologie 25, 39-48.

Hecky, R.E. \& Fee, E.J. (1981). Primary production and rates of algal growth in Lake Tanganyika. Limnology and Oceanography 26, 532-547.

Hecky, R.E. \& Kling, H. (1981). The phytoplankton and protozooplankton of the euphotic zone of Lake Tanganyika: species composition, biomass, chlorophyll content, and spatiotemporal distribution. Limnology and Oceanography 26, 548-564.

Hecky, R.E. \& Kling, H.J. (1987). Phytoplankton ecology of 
the great lakes in the rift valleys of Central Africa. Archiv für Hydrobiologie Beiheft Ergebnisse der Limnologie 25, 197-228.

Hecky, R.E., Fee, E.J., Kling, H.J. \& Rudd, J.W.M. (1981).

Relationship between primary production and fish production in Lake Tanganyika. Transactions of the American Fisheries Society 110, 336-345.

Hecky, R.E., Bugenyi, F.W.B., Ochumba, P., Talling, J.F., Mugidde, R., Gophen, M. \& Kaufman, L. (1994). Deoxygenation of the deep-water of Lake Victoria, East Africa. Limnology and Oceanography 39, 1476-1481.

Hustedt, F. (1949). Exploration du Parc National Albert-Mission H. Damas 1935-1936, Fascicule 8: Süsswasser-Diatomeen. Institut des Parcs Nationaux du Congo Belge, Brussels. 199 pp.

Iles, T.D. (1960). Activities of the organization in Nyasaland. In: Annual Report n. 9, pp. 7-41. Joint Fisheries Research Organisation. Northern Rhodesia, Governement Printer, Lusaka.

Isumbisho, M., Sarmento, H., Kaningini, B., Micha, J.C. \& Descy, J.-P. (2006). Zooplankton of Lake Kivu, East Africa, half a century after the Tanganyika sardine introduction. Journal of Plankton Research 28, 971-989.

Johnson, T.C. (1996). Sedimentary processes and signals of past climatic change in the large lakes of the East African Rift Valley. In: The Limnology, Climatology and Paleoclimatology of the East African Lakes (eds T.C. Johnson \& E.O. Odada), pp. 367-411. Gordon \& Breach Publ., Amsterdam.

Karl, D.M., Bidigare, R.R. \& Letelier, R.M. (2002). Sustained and aperiodic variability in organic matter production and phototrophic microbial community structure in the North Pacific Subtropical Gyre. In: Phytoplankton Productivity. Carbon Assimilation in Marine and Freshwater Ecosystems (eds P. le B. Williams, D. Thomas \& C.S. Reynolds), pp. 222-264. Blackwell Science, Oxford.

Kilham, P. \& Kilham, S.S. (1990). Endless summer: internal loading processes dominate nutrient cycling in tropical lakes. Freshwater Biology 23, 379-389.

Kilham, P., Kilham, S.S. \& Hecky, R.E. (1986). Hypothesized resource relationships among African planktonic diatoms. Limnology and Oceanography 31, 1169-1181.

Kling, H.J., Mugidde, R. \& Hecky, R.E. (2001). Recent changes in the phytoplankton community of Lake Victoria in response to eutrophication. In: The Great Lakes of the World (GLOW): Foodweb, Health and Integrity (eds M. Munawar \& R.E. Hecky), pp.
47-65. Leiden (The Netherlands), Backhuys.

Kurki, H., Vuorinen, I., Bosma, E. \& Bwebwa, D. (1999). Spatial and temporal changes in copepod zooplankton communities of Lake Tanganyika. Hydrobiologia 407, 105-114.

Langenberg, V.T., Nyamushahu, S., Roijackers, R. \& Koelmans, A.A. (2003). External nutrient sources for Lake Tanganyika. Journal of Great Lakes Research 29, Suppl. 2, 169-180.

Lehman, J.T. \& Branstrator, D.K. (1994). Nutrient dynamics and turnover rates of phosphate and sulfate in Lake Victoria, East Africa. Limnology and Oceanography 39, 227-233.

Lehman, J. T. (1996). Pelagic food webs of the East African Great Lakes. In: The Limnology, Climatology and Paleoclimatology of the East African Lakes (eds T.C. Johnson \& E.O. Odada), pp. 281-301. Gordon \& Breach Publ., Amsterdam.

Lemoalle, J., Adeniji, A., Compère, P., Ganf, G.G., Melack, J. \& Talling, J.F. (1981). Phytoplankton. In: The Ecology of and Utilization of African Inland Waters (eds J.-J. Symoens, M. Burgis \& J.J. Gaudet), pp. 37-50. UNEP, Nairobi.

Lévêque, C. (1995). Role and consequences of fish diversity in the functioning of African freshwater ecosystems: a review. Aquatic Living Resources 8, 59-78.

Lewis, W.M.J. (2000). Basis for the protection and management of tropical lakes. Lakes \& Reservoirs: Research and Management $5,35-48$

Margalef, R. (1994). Diversity and biodiversity - their possible meaning in relation with the wish for sustainable development. Anais da Academia Brasileira de Ciências 66 (Suppl. 1), 3-14.

Margalef, R. (1997). Our Biosphere. Excellence in Ecology, Book 10, ed. O. Kinne. International Ecology Institute, Oldendorf/Luhe, Germany. 176 pp.

Melack, J.M. (1976). Primary productivity and fish yields in tropical lakes. Transactions of the American Fisheries Society 105, 575-580.

Mugidde, R. (1993). The increase in phytoplankton primary productivity and biomass in Lake Victoria (Uganda). Verhandlungen der Internationalen Vereinigung für theoretische und angewandte Limnologie 25, 846-849.

Odada, E.O., Olago, D.O., Bugenyi, F., Kulindwa, K., Karimumuryango, J., West, K., Ntiba, M., Wandiga, S., AlooObudho, P. \& Achola, P. (2003). Environmental assessment of the East African Rift Valley lakes. Aquatic Sciences 65, 254-271.

Odada, E.O., Olago, D.O., Kulindwa, K., Bugenyi, F., West, K., 
Ntiba, M., Wandiga, S. \& Karimumuryango, J. (2004). East African Rift Valley Lakes. GIWA Regional Assessment 47. University of Kalmar, Sweden, on behalf of United Nations Environment Programme. 141 pp. + annexes.

Oguto-Ohwayo, R. \& Hecky, R.E. (1991). Fish introductions in Africa and some of their implications. Canadian Journal of Fisheries and Aquatic Sciences 48, Suppl. 1, 8-12.

O'Reilly, C.M., Alin, S.R., Plisnier, P.-D., Cohen, A.S. \& Mckee, B.A. (2003). Climate change decreases aquatic ecosystem productivity of Lake Tanganyika, Africa. Nature 424, 766-768.

Patterson, G. \& Kachinjika, O. (1995). Limnology and phytoplankton ecology. In: The Fishery Potential and Productivity of the Pelagic Zone of Lake Malawi/Niassa - Scientific Report of the UK/SADC Pelagic Fish Resource Assessment Project (ed. A. Menz), pp. 1-67. Natural Resources Institute, Overseas Development Administration.

Pedrós-Alió, C. (2006). Marine microbial diversity: can it be determined? Trends in Microbiology 14, 257-263.

Pirlot, S. (2006). Le bactérioplancton du Lac Tanganyika. Biomasse, production et devenir trophique. $\mathrm{PhD}$ thesis, University of Namur, Presses universitaires de Namur, Namur, Belgium (unpublished). $267 \mathrm{pp}$.

Pirlot, S., Vanderheyden, J., Descy, J.-P. \& Servais, P. (2005). Abundance and biomass of heterotrophic micro-organisms in Lake Tanganyika. Freshwater Biology 50, 1219-1232. (Corrigendum 2006: Correction of biomass estimates for heterotrophic micro-organisms in Lake Tanganyika. Freshwater Biology 51, 984-985).

Pirlot, S., Unrein, F., Descy, J.-P., Servais, P. (2007). Fate of heterotrophic bacteria in Lake Tanganyika (East Africa). FEMS Microbiology Ecology 62, 354-364.

Plisnier, P.-D. (2000). Recent climate and limnology changes in Lake Tanganyika. Verhandlungen der Internationalen Vereinigung für theoretische und angewandte Limnologie 27, 2670-2673.

Plisnier, P.-D. (2004). Probable impact of global warming and ENSO on Lake Tanganyika. Bulletin des Séances Académie Royale des Sciences d'Outre-mer 50, 185-196.

Reynolds, C.S., Reynolds, S.N., Munawar, I.F. \& Munawar, M. (2000). The regulation of phytoplankton population dynamics in the world's largest lakes. Aquatic Ecosystem Health and Management 3, 1-21.

Sarmento, H. (2006). Phytoplankton ecology of Lake Kivu(Eastern
Africa). PhD thesis, University of Namur, Presses universitaires de Namur, Namur, Belgium (unpublished). 182 pp.

Sarmento, H., Isumbisho, M. \& Descy, J.-P. (2006). Phytoplankton ecology of Lake Kivu (eastern Africa). Journal of Plankton Research 28, 815-829.

Sarmento, H., Leitao, M., Stoyneva, M., Couté, A., Compère, P., Isumbisho, M. \& Descy, J. P. (2007). Diversity of pelagic algae of Lake Kivu (East Africa). Cryptogamie-Algologie 28, 245-269.

Sarmento, H., Unrein, F., Isumbisho, M., Stenuite, S., Gasol, J.A. \& Descy, J.-P. (2008). Abundance and distribution of picoplankton in tropical, oligotrophic Lake Kivu, eastern Africa. Freshwater Biology (in press). doi:10.1111/j.1365-2427.2007.01939.x.

Sarvala, J., Langenberg, V.T., Salonen, K., Chitamwebwa, D., Coulter, G.W., Huttula, T., Kanyaru, R., Kotilainen, P., Makasa, L., Mulimbwa, M.N. \& Mölsä, H. (2006). Fish catches from Lake Tanganyika mainly reflect changes in fishery practices, not climate. Verhandlungen der Internationale Vereinigung für theoretische und angewandte Limnologie, 29, 1182-1188.

Schmid, M., Halbwachs, M., Wehrli, B. \& Wüest, A. (2005). Weak mixing in Lake Kivu: new insights indicate increasing risk of uncontrolled gas eruption. Geochemistry, Geophysics, Geosystems 6, 1-11. doi:10.1029/2004GC000892.

Schmidle, W. (1898). Die von Professor Dr. Volkens und Dr. Stuhlmann in Ost-Afrika gesammelten Desmidiaceen. Botanische Jahrbücher 26, 1-59.

Schmidle,W. (1902). Das Chloro- und Cyanophyceenplankton der Nyassa und einiger anderer innerafrikanischer seen. Botanische Jahrbücher 33, 1-33.

Silsbe, G.M., Hecky, R.E., Guildford, S.J. \& Mugidde, R. (2006). Variability of chlorophyll $a$ and photosynthetic parameters in a nutrient-saturated tropical great lake. Limnology E Oceanography 51, 2052-2063

Stenuite, S., Pirlot, S., Hardy, M.-A., Sarmento, H., Tarbe, A.-L., Leporcq, B. \& Descy, J.-P. (2007). Phytoplankton production and growth rate in Lake Tanganyika: evidence of a decline in primary productivity in recent decades. Freshwater Biology 52, 2226-2239.

Stoyneva, M. P., Gaertner, G., Cocquyt, C. \& Vyverman, W. (2005). Closteriopsis petkovii n. sp. - a new green alga from Lake Tanganyika. Phyton 45, 237-247.

Stoyneva, M., Gärtner, G., Cocquyt, C. \& Vyverman, W. (2006). Eremosphaera tanganyikae sp. nov. (Trebouxiophyceae), a new 
species from Lake Tanganyika. Belgian Journal of Botany 139, 313.

Stoyneva, M.P., Descy, J.-P. \& Vyverman, W. (2007a). Green algae in Lake Tanganyika: is morphological variation a response to seasonal changes? Hydrobiologia 578, 7-16.

Stoyneva, M., Cocquyt, C., Gärtner, G. \& Vyverman, W. (2007b). Oocystis lacustris Chod. (Chlorophyta, Trebouxiophyceae) in Lake Tanganyika (Africa). Linzer Biologische Beiträge 39, 571- 632.

Stoyneva, M., Ingolič, E., Kofler, W. \& Vyverman, W. (2008). Siderocelis irregularis Hindák in Lake Tanganyika (Africa). Biologia (Bratislava) (in press).

Talling, J.F. (1957). Some observations on the stratification of Lake Victoria. Limnology and Oceanography 2, 213-221.

Talling, J.F. (1966). The annual cycle of stratification and phytoplankton growth in Lake Victoria (East Africa). Internationale Revue der Gesamten Hydrobiologie 51, 545-621.

Talling, J.F. (1986). The seasonality of phytoplankton in African lakes. Hydrobiologia 138, 139-160.

Talling, J.F. (1987). The phytoplankton of Lake Victoria (East Africa). Archiv für Hydrobiologie Beiheft Ergebnisse der Limnologie 25, 229-256.

Tietze, K., Geyh, M., Müller, H., Schröder, L., Stahl, W. \& Wehner, H. (1980). The genesis of the methane in Lake Kivu (Central Africa). Geologische Rundschau 69, 452-472.

Van Meel, L. (1954). Le Phytoplancton. Exploration Hydrobiologique du Lac Tanganyika (1946-1947) - Résultats scientifiques. Institut Royal des Sciences Naturelles de Belgique, Brussels. pp. $681+$ $76 \mathrm{pl}$.

Verburg, P., Hecky, R.E. \& Kling, H. (2003). Ecological consequences of a century of warming in Lake Tanganyika. Science 301, 505- 507.

Verburg, P., Hecky, R.E. \& Kling, H.J. (2006). Climate warming decreased primary productivity in Lake Tanganyika, inferred from accumulation of dissolved silica and increased transparency. Comment to Sarvala et al. 2006 (Verh. Internat. Verein. Limnol. 29, 1182-1188). Verhandlungen der Internationalen Vereinigung für theoretische und angewandte Limnologie 29, 2335- 2338.

Verschuren, D. (2003). The heat on Lake Tanganyika. Nature 424, 731-732.

Verschuren, D., Johnson, T.C., Kling, H.J., Edgington, D.N., Leavitt,
P.R., Brown, E.T., Talbot, M.R. \& Hecky, R.E. (2002). History and timing of human impact on Lake Victoria, East Africa. Proceedings of the Royal Society of London Series (B) 269, 289-294.

Vuorio, K., Nuottajarvi, M., Salonen, K. \& Sarvala, J. (2003). Spatial distribution of phytoplankton and picocyanobacteria in Lake Tanganyika in March and April 1998. Aquatic Ecosystem Health and Management 6, 263-278.

West, G.S. (1907). Report on the freshwater algae, including phytoplankton, of the Third Tanganyika Expedition conducted by Dr. W.A. Cunnington, 1904-1905. Journal of the Linnean Society: Botany 38, 81-197.

Woloszynska, J. (1914). Zellpflanzen Ostafrikas, V. Studien über das Phytoplankton des Victoriasees. Hedwigia 55, 184-223.

\section{Author Profiles}

Jean-Pierre Descy has a PhD in Botany from the University of Liège (Belgium, 1975) and is Professor at l'University of Namur (since 1994). His research area is freshwater ecology, with a principal interest in the study of microorganisms. His work has been devoted to assessment of the biological and ecological quality of surface waters and to ecosystem function (phytoplankton ecology, trophic relationships, contribution to modelling).

Hugo Sarmento comes from Portugal and holds a $\mathrm{PhD}$ in aquatic sciences from the University of Namur (Belgium), where he researched the ecology of phytoplankton of the East African Great Lakes (especially lakes Kivu and Tanganyika). At present, he has a post-doctoral research grant from the Spanish Government to study the interactions between phytoplankton and heterotrophic bacteria in marine systems, mainly the bacterial assemblage responses to the dissolved organic carbon released by different phytoplankton species. He is also developing the application of MAR-FISH (Micro Autoradiography coupled with Fluorescent In Situ Hybridation) with labelled organic carbon excreted from algae. 